\title{
Practitioner Perspectives on Cataloging Education for Entry-Level Academic Librarians
}

\author{
Karen M. Letarte, Michelle R. Turvey, Dea Borneman, \\ and David L. Adams
}

The role of cataloging education within the library profession is a topic of considerable interest and debate. Fifty-five heads of reference and sixty-five heads of cataloging in Association of Research Librarians institutions responded to a survey based upon the Association for Library Collections and Technical Services Educational Policy Statement, Appendix: Knowledge and Skills, Intellectual Access and Information Organization, concerning the importance of cataloging competencies for all entry-level academic librarians. The survey found that practitioners agreed upon a definite set of core cataloging competencies that all entrylevel academic librarians should possess. This finding holds larger implications for library education for academic librarians and for the profession as a whole.

Karen M. Letarte (kmletart@unity.ncsu. edu) is Assistant Head of Cataloging, North Carolina State University Libraries, Raleigh. Michelle R. Turvey (mrt428f@smsu.edu) is Cataloging Librarian, Duane G. Meyer Library, Southwest Missouri State University, Springfield. Dea Borneman (dab217f@ smsu.edu) is the Greenwood Library Media Specialist, Southwest Missouri State University, Springfield. David L. Adams (dla977f@ smsu.edu) is Head of Systems, Duane G. Meyer Library, Southwest Missouri State University, Springfield.

Manuscript received July 13, 2001; accepted November 7, 2001.
Tn an age when library competencies are widely discussed and considered and Iincreasing numbers of libraries are seeking to outsource technical services functions, where do basic cataloging competencies for new graduates stand? The first Congress on Professional Education addressed the topic of initial preparation of librarians for the field from a variety of angles, including core values, core competencies, accreditation, and stratification (American Library Association 1999).

Interest in the question of core cataloging competencies for academic librarians developed after one of the authors was involved in the recruitment process for two academic library cataloging positions at Southwest Missouri State University (SMSU). Throughout the search process, a striking variation in basic cataloging competencies was noted among the candidates. Far from being an isolated instance, this variation occurred in candidate pools for a number of searches the library has conducted to fill existing and newly created professional positions in the past five years. The occurrence of such variation in cataloging education for both cataloging and noncataloging positions raised questions concerning cataloging education in American Library Association-accredited programs. What is the current state of cataloging education for all librarians? How do practitioners view its importance in the library science curriculum?

A review of the current literature on the roles of cataloging and cataloging education further fueled the initial questions. In the literature, a number of articles have focused on the perceived divide between practitioners and educators on the role of cataloging education within the library and information science 
graduate degree program. Arguing from the practitioner's perspective, Morris and Wool (1999) assert that quality cataloging still has value today in terms of its influence on effective reference services, collection management, resource sharing, and database automation.

While Morris and Wool, as practitioners, emphasize the value of cataloging and cataloging education, Fallis and Frické, speaking as library educators, characterize cataloging as a practical skill and thus not appropriate for graduate-level education. "While much of what librarians do requires that theoretical, graduate-level education, librarians also need certain practical skills. Many practical skills of librarianship (including how to catalog books) are simply not appropriate material for graduate-level courses" $(1999,44)$. However, the ALA-accredited master's degree has traditionally included elements of both theory and practice for all areas of librarianship. To advocate the removal of cataloging education from the graduate curriculum due to a perception that it is limited to purely mechanical or technical elements overlooks the fact that other areas of graduate curriculum teach "how to" or basic skills and competencies as well.

The Association for Library Collections and Technical Services (ALCTS) Educational Policy Statement (1995) stresses a combination of theoretical and practical knowledge. Examples of other practical skills and competencies within the graduate curriculum include how to conduct a reference interview, budgeting in management, and the acquisitions side of collection development. Given the divergent views on the roles of cataloging and cataloging education that exist in the literature, an examination of the current status of cataloging education in library and information science graduate curriculum provides useful insights.

\section{Literature Review}

McAllister-Harper, Vellucci, and Spillane conducted three of the most recent studies addressing cataloging education. McAllister-Harper (1993) reviewed the content of cataloging and classification courses at sixteen ALA-accredited doctoral programs. While it provided some insight, the study was greatly limited by the small sample size and its focus on doctoral programs.

Both Vellucci and Spillane examined the requirements for basic cataloging courses within ALA-accredited masters programs. Specifically, Vellucci (1997) studied bulletins of fifty-two U.S. and Canadian ALA-accredited library schools in order to determine the strength of cataloging in the master's level curriculum and program requirements for cataloging. Vellucci reviewed the bulletins in light of the final report of the Cataloger Training Task Group of the Cooperative Cataloging Council and the ALCTS Educational Policy Statement (1995). The findings revealed a general decline in the number of required basic cataloging courses and an increase in the number of more general courses that incorporate cataloging with indexing, abstracting, and other methods of organization. A greater variety of offerings in advanced cataloging courses were also noted.

Spillane (1999) investigated the number of required introductory cataloging courses listed in the bulletins of fifty-six ALA-accredited schools and confirmed the decline in the number of required basic cataloging courses. Although the number of required introductory cataloging courses had decreased, a greater overall number of cataloging courses was being offered. However, the increase in the overall number of cataloging courses offered could be attributed to several factors, including the growth of new formats such as DVDs, Internet resources, electronic serials, and emerging metadata standards. A significant drawback in Spillane's method was the use of the course bulletin as the primary information source. Bulletins do not necessarily represent regularly offered cataloging courses; moreover, course listings in bulletins are revised infrequently in comparison to course schedules and may not readily reflect the practices of individual faculty members. Another difficulty of using bulletins as the information source arises in relation to the definition of core cataloging courses. Each institution defines "core" somewhat differently. In some programs, a "core" cataloging course is required for all students, while in others, it is one of a number of core options. Lacking an operational definition of core, the reader is forced to guess how variations between program requirements were accounted for in the study.

Both Vellucci and Spillane demonstrate the changing nature of cataloging education and the general decline in the number of basic cataloging courses over time. This raises the question of the importance of cataloging education for all entry-level librarians, something for which, not surprisingly, catalogers have advocated for some time. "If for no other reason than the practical necessity of understanding and planning for automated catalogs, every M.L.S. graduate needs coursework in cataloging. To the noncataloger, catalog information is more a commodity than a scholarly resource" (Urbanski 1992, 58). Thus, cataloging education provides a useful framework for other library activities, not just cataloging.

Ironically, as the number of basic cataloging courses has declined in favor of a more integrated course model with cataloging as only one component, bibliographic control needs have become even more sophisticated. A key example can be found in the area of electronic resources where differing levels of granularity present new levels of complexity for bibliographic description. Alternate avenues of access for electronic resources, beyond the library catalog, are being explored through the use of various metadata schemata. 
Metadata is defined as data about data. Often, particularly in the case of electronic resources, this data is embedded in the object that is being described. While traditional cataloging represents one type of metadata, the field of metadata is broader than traditional cataloging. Each metadata standard tends to reflect the needs of the particular community that created it. OCLC's Dublin Core standard, for example, attempts to create a flexible framework for describing electronic resources that may be used easily by catalogers and noncatalogers alike. But whether access to electronic resources is provided via use of embedded metadata or through the library catalog, the need for access is critical. "Without bibliographic control, librarians and other staff cannot do their work and library users cannot use the collections effectively. Without librarians and staff, the library is merely a warehouse" (Gorman 1999, 6). At a time when cataloging education seems to be declining, the need for librarians who understand cataloging is increasing.

Beyond cataloging education, research into competencies for librarians continues to be of great interest within the profession. Studies on competencies are plentiful, yet many of the topics have not been revisited in recent years. Several studies focused on competencies within particular specialties (Powell and Creth 1986; Green 1993) and on competencies that recent graduates should possess (White and Paris 1985; Buttlar and DuMont 1989). Within cataloging, various studies have examined basic cataloging competencies that entry-level catalogers should possess (CCS Task Force on Education and Recruitment for Cataloging Report 1986; MacLeod and Callahan 1995; Hill 1997). A subtopic under cataloging competencies for entry-level catalogers is the debate over the teaching of cataloging theory versus cataloging practice (Riemer 1993; Speller 1993; Vellucci 1997).

However, nothing within the competencies literature attempts to address a set of cataloging competencies that all entry-level academic librarians should possess. In light of the literature on the fluctuating state of cataloging education and the gaps in competencies research, questions arose concerning cataloging education in a broader context.

\section{Research Problems}

During the recruitment process for various library positions at SMSU, questions arose concerning the widely varying levels of cataloging education among applicants. The results from a follow-up literature survey on the topic of cataloging education raised still more questions. In order to more fully consider questions raised, the authors decided to focus on them as they relate to academic libraries. Spillane (1999) and Vellucci (1997) have documented a decrease in the number of required cataloging courses in ALA-accredited masters programs, raising the following questions as they relate to academic librarians:

- Do public and technical services practitioners in academic libraries believe that cataloging education is important for all entry-level academic librarians?

- Is there a basic set of cataloging competencies that public and technical services practitioners in academic libraries believe that all entry-level academic librarians should possess?

- Are there differences in the ways that public and technical services practitioners in academic librarians view the importance of cataloging competencies for all entry-level academic librarians?

- Do practitioners view practical cataloging knowledge as being less important than theoretical knowledge?

These research questions hold implications for users and librarians alike. The assumption is that a basic understanding of cataloging has value beyond technical services divisions, since the catalog is one of the library's primary and most expensive finding aids. The quality of the bibliographic data has a powerful impact on the functionality of library systems. A basic understanding of cataloging also has implications for library users and those assisting users with the library catalog and other tools (e.g., indexes, Internet searching, etc.).

\section{Method}

To explore the research questions, a survey was designed to elicit opinions from academic library practitioners in both public and technical services concerning the importance of cataloging competencies for all entry-level academic librarians. For the purpose of this study, entry-level was operationally defined as the first professional position following receipt of the ALA-accredited master's degree. The pool of academic librarians for this study was defined as professional librarians working in Association of Research Libraries (ARL) institutions whose primary mission is to serve the students of the parent institution.

While the ALCTS Educational Policy Statement (1995) was written specifically with technical services in mind, many of the tenets can be applied to a broader audience. "A fundamental knowledge of the ways in which information is organized, stored, and retrieved is important for librarians in all areas of the library. Intellectual access and information organization provide the structures and pattern of control found in all information-access components of libraries" (ALCTS Educational Policy Statement 1995). The document contains suggested competencies for a variety of specialties within technical services (information organization, 
acquisitions and collection development, preservation). For the purposes of this study, the focus was on only those competencies related to information organization or cataloging.

Because cataloging is an area of value to the whole of librarianship, a survey was designed to gather information on the opinions of practitioners in both public and technical services. The survey was based on the competencies found in the ALCTS Educational Policy Statement, Appendix: Knowledge and Skills, Intellectual Access and Information Organization (1995). The survey sought to measure whether or not heads of reference and heads of cataloging in ARL member institutions viewed the listed cataloging competencies as important for all entry-level academic librarians, rather than simply technical services librarians.

Letters soliciting survey participation were sent via email to 111 current heads of reference and 111 heads of cataloging at ARL academic libraries. Research library members with no university affiliation (e.g., Library of Congress, etc.) were omitted from the sample. The academic ARL member libraries include a wide range of institutions in a broad array of geographic settings in both the United States and Canada.

Every effort was made to identify the current heads of reference and heads of cataloging departments or their equivalents. In many instances, multiple campus libraries existed with several including more than one reference department. When this scenario was encountered, the head of the reference department in the main library with the most general collection was preferred. On occasion, a separate cataloging department was associated with a branch (e.g., medical library with separate cataloging unit). In cases where a variety of cataloging functions existed in separate units (serials, copy cataloging, original cataloging, cataloging by subject, etc.), the head of the original monographic cataloging unit was preferred.

The primary source of contact information was individual library Web pages supplemented by online faculty and staff directories. If information on a library's Web pages proved incomplete, the university's online directory was consulted. Remaining gaps were filled by consulting Hopkins (2000) or by contacting the institutions directly either by e-mail or telephone. Contact information, once completed, was then entered into a FileMaker Pro database.

Survey questions were based on the ALCTS Educational Policy Statement, Appendix: Knowledge and Skills, Intellectual Access and Information Organization (1995), addressing both broad and specific cataloging competencies. Although the statement makes no mention of specific type of library (academic, public, school, special), academic libraries were the focus of the survey. For the purposes of this study, skills and competencies are used interchangeably.
In order to prevent unsolicited participation, participants were given a user name and password to access the survey. The only required elements on the survey were the department type (public services or technical services) and e-mail address. Completed surveys arrived via e-mail and were then transferred to a secure server. Pretesting of the survey within the researchers' home institution ensured there were no technical difficulties in form submission or in survey display using different browsers and different platforms. Finally, although responses were anonymous, respondents were asked to provide their e-mail address so that duplicate responses could be detected and follow-up messages for nonresponses sent. Survey responses were analyzed using SPSS statistical software.

\section{Results}

The survey was administered to 111 heads of reference and 111 heads of cataloging in ARL libraries. Of the 222 individuals surveyed, 120 replied ( 55 public services, 65 technical services) for a response rate of $54 \%$. The survey included twenty-five questions focusing on thirty-nine cataloging competencies. Participants were asked to rank the importance of the cataloging skills and competencies listed for all entry-level academic librarians, regardless of their specific area of employment. Each skill or competency was ranked according to the following four-point scale, where: $1=$ Essential; $2=$ Important; $3=$ Desirable, but not necessary; and $4=$ Unimportant.

The first research question asked whether public and technical services practitioners in academic libraries believe that cataloging education is important for all entry-level academic librarians. Results clearly indicate strong agreement among all respondents that the competencies surveyed are important, with means for all competencies falling within the range of essential to important. Table 1 displays the means for the competencies as ranked by all respondents in order from the lowest to the highest means, along with the accompanying standard deviation.

The means of all the competencies listed in table 1 fall within a relatively small range, from 1.11 to 2.80 , where (1) is essential, (2) is important, and (3) is desirable, but not necessary. All of the means thus fall well below 3.0, into the range of essential to important. Furthermore, the differences between many of the means are slight, and most have relatively small standard deviations, indicating a high level of agreement among respondents. The means indicate that public and technical services practitioners in academic libraries consider cataloging education to be valuable for entry-level academic librarians.

One respondent commented, "All the competencies listed here are very important if a person is going to be suc- 
Table 1. Cataloging Competencies for All Entry-Level Academic Librarians

\begin{tabular}{|c|c|c|c|}
\hline Competency & No. & Mean & SD \\
\hline Ability to read and interpret a bibliographic record in an OPAC & 120 & 1.11 & .4058 \\
\hline Understanding of information-seeking behaviors of users & 120 & 1.48 & 6349 \\
\hline Knowledge of the ways in which searching techniques affect precision and recall & 120 & 1.53 & .6208 \\
\hline Knowledge of the theory of information organization and intellectual access & 120 & 1.58 & .7051 \\
\hline Ability to evaluate information-retrieval systems in relation to user needs and information-seeking behaviors & 119 & 1.68 & .7804 \\
\hline Understanding of the activities that must be performed to provide the products and services users need & 119 & 1.71 & .7265 \\
\hline Library of Congress Subject Headings & 119 & 1.74 & .7531 \\
\hline Awareness of bibliographic utilities & 119 & 1.76 & .7808 \\
\hline MARC format & 117 & 1.79 & .8463 \\
\hline Library of Congress Classification & 119 & 1.76 & .6975 \\
\hline Understanding the relationship between classification schemes and shelf order & 118 & 1.79 & .7719 \\
\hline Cataloging tools: Basic knowledge of & 119 & 1.79 & .8221 \\
\hline \multicolumn{4}{|l|}{ Understanding the relationship of the research library's units to the provision of intellectual } \\
\hline access to information resources & 118 & 1.80 & .7072 \\
\hline Knowledge of the ways in which data structures affect precision and recall & 120 & 1.79 & 6969 \\
\hline Classification: Knowledge of theory & 118 & 1.86 & .7270 \\
\hline Knowledge of the theoretical basis for retrieval & 120 & 1.87 & .7839 \\
\hline Knowledge of bibliographic relationships underlying database design & 120 & 1.88 & .7003 \\
\hline Describing, identifying, and showing relationships among materials: Knowledge of theory & 120 & 1.89 & .6835 \\
\hline Subject analysis: Knowledge of theory & 119 & 1.92 & .7448 \\
\hline Knowledge of the basic database design concepts & 119 & 2.00 & .7591 \\
\hline Ability to develop and apply syndetic structure and controlled vocabulary in information retrieval systems & 117 & 2.10 & .8135 \\
\hline Subject analysis: Knowledge of methods for & 117 & 2.13 & .7490 \\
\hline Describing, identifying, and showing relationships among materials: Knowledge of methods for & 119 & 2.08 & 6960 \\
\hline Anglo-American Cataloguing Rules & 119 & 2.08 & .8395 \\
\hline Knowledge of sources of bibliographic records & 118 & 2.11 & .8142 \\
\hline Indexing: Knowledge of theory & 119 & 2.11 & .7568 \\
\hline Classification: Knowledge of methods for & 117 & 2.15 & .7265 \\
\hline Knowledge of relevant national and international cataloging standards & 119 & 2.15 & .7438 \\
\hline Thesaurus creation: Knowledge of theory & 120 & 2.21 & .7436 \\
\hline Knowledge of principles for designing user-driven information retrieval systems & 120 & 2.21 & .7875 \\
\hline Cataloging tools: Working knowledge of & 116 & 2.34 & .8016 \\
\hline HTML & 119 & 2.30 & .8291 \\
\hline Indexing: Knowledge of methods for & 118 & 2.35 & .7224 \\
\hline Thesaurus creation: Knowledge of methods for & 118 & 2.52 & .6757 \\
\hline Dublin Core & 114 & 2.61 & .8038 \\
\hline Core Record Standard & 114 & 2.63 & .8121 \\
\hline Library of Congress Rule Interpretations & 119 & 2.53 & .9372 \\
\hline Knowledge of state-of-the art research and practice in cataloging and classification & 119 & 2.66 & .7281 \\
\hline Dewey Decimal Classification & 118 & 2.80 & .8529 \\
\hline
\end{tabular}

Scale: $1=$ Essential $2=$ Important $3=$ Desirable but not necessary $4=$ Unimportant

cessful in a research library position. It's difficult to decide if one is essential or 'just' important. Many local practices and some other skills can be taught on the job, but the more prepared a new librarian is, the better for the person and the library."

The second research question concerned the existence of a basic set of cataloging competencies for all entry-level academic librarians. With such strong agreement about the importance of the competencies listed in table 1, it appears that there is a basic set of cataloging competencies that public and technical services practitioners in academic libraries believe all entry-level academic librarians should possess.

Results indicate that the practitioners surveyed believe that a number of the competencies examined are essential for entry-level librarians. An examination of the means for competencies in table 1 reveals that a surprising $51 \%$ have means that are less than or equal to 2.00. These competencies, clearly recognized by respondents as important, could then be considered the set of core cataloging competencies. For the purposes of this study, core competencies are defined as competencies with means between 1.00 and 2.00. Of the thirty-nine specific competencies surveyed, twenty competencies have means between 1.00 and 2.00. Four additional competencies have means between 2.00 and 2.10.

Respondents substantially agreed that the most important competency, with a mean of 1.11 ( $\mathrm{SD}=.4058)$, is the ability to read and interpret a bibliographic record in an OPAC. Respondents agreed upon the importance of this 
competency more strongly than any other that was surveyed. The fact that this mean is so much lower than the others suggests that respondents view its importance extending well beyond the field of cataloging alone.

The ability to read and interpret a bibliographic record in the OPAC encompasses knowledge of many of the other competencies surveyed. It involves broad knowledge of descriptive and subject cataloging, and knowledge of cataloging tools and the standards that govern each. Competencies involving knowledge of descriptive and subject cataloging and cataloging tools include the following:

- basic knowledge of cataloging tools

- working knowledge of cataloging tools

- Anglo-American Cataloguing Rules

- Library of Congress Rule Interpretations

- MARC format

- Library of Congress Classification

- Dewey Decimal Classification

- Library of Congress Subject Headings

- knowledge of relevant national and international cataloging standards

The ability to read and interpret a bibliographic record in the OPAC also involves competencies relating to how the OPAC is created and structured to facilitate retrieval. Competencies related to the use of the OPAC itself include the following:

- knowledge of bibliographic relationships underlying database design

- knowledge of the ways in which data structures affect precision and recall

- knowledge of the ways in which searching techniques affect precision and recall

- ability to develop and apply syndetic structure and controlled vocabulary in information retrieval systems

- knowledge of methods for describing, identifying, and showing relationships among materials

- knowledge of methods for indexing

- knowledge of methods for thesaurus creation

- knowledge of methods for subject analysis

- knowledge of information organization and intellectual access theory

The means for all of the narrower competencies (means of 1.53 and higher) related to the ability to read and interpret a bibliographic record in the OPAC are all higher than the mean for the OPAC competency itself (mean of 1.11). Thus, although practitioners value the broader ability to read and interpret a bibliographic record in the OPAC over the more specific cataloging and OPAC-related competencies, all of the competencies are of value to practitioners.
One librarian stated, "New librarians need to understand the concepts of how databases are constructed, how records are constructed, and how to best retrieve information using basic searching techniques. The actual standards behind the database creation are less important as systems proliferate." Another librarian commented, "On the other hand, I do think that we should be hiring people with a pretty in-depth understanding of basic database structure, since this teaches a lot about how information is organized behind the scenes. It also helps the new hire to understand how larger data structures like the OPAC, reference databases, search engines, etc. work." Thus, while OPACs may not necessarily be the only database commonly searched by librarians, the ability to read and interpret a bibliographic record in the OPAC is still viewed as the most important of the listed competencies and encompasses numerous other competencies.

The next most important competency, with a mean of 1.48 , is understanding of information-seeking behaviors of users. This competency addresses a fairly broad area of knowledge and indicates, in fact, an observable trend in the responses. The six most important competencies are also the broadest and show that practitioners believe a broad knowledge of data structures, user behavior, and information organization and access are essential for entry-level academic librarians.

The third research question asked if there are differences in the ways that public and technical services practitioners in academic libraries view the importance of cataloging competencies for all entry-level academic librarians. Results shown in table 1 demonstrate strong agreement among all respondents about the importance of the competencies surveyed. However, these results do not provide the entire picture. Respondents from both groups basically agreed in their responses overall; however, some differences in their rankings of the top ten core competencies emerge and are further discussed below.

\section{Public Services and Technical Services Respondents: Overall Rankings}

Mean responses for all items from public and technical services practitioners in academic libraries were compared to determine if there are any statistically significant differences between the two groups on how cataloging competencies are viewed for all entry-level academic librarians. The hypothesis was that there would be statistically significant differences in how public and technical services practitioners in academic libraries viewed the cataloging competencies. The null hypothesis was that there would be no significant difference between the responses of public services and technical services practitioners. A 
two-tailed independent $t$ test with the confidence interval set at 0.95 was performed, with a p-value of less than or equal to .05 indicating a statistically significant difference in response between the two groups. The results from the t test indicated that, with the exception of nine specific competencies (see table 2), respondents in both groups agreed upon the importance of cataloging competencies for entry-level academic librarians.

Public and technical services practitioners agreed on all but the following nine competencies:

- understanding of information-seeking behaviors of users

- ability to evaluate information-retrieval systems in relation to user needs and information-seeking behaviors

- Library of Congress Classification

- knowledge of the basic database design concepts

- HTML

- basic knowledge of cataloging tools

- knowledge of principles for designing user-driven information retrieval systems

- Anglo-American Cataloguing Rules

- knowledge of relevant national and international cataloging standards

Thus, the null hypothesis was rejected only for the nine competencies above. Though a significant statistical difference was found for the nine competencies, results shown in table 1 confirm that the practical significance of this slight difference is minimal. With the exception of the nine competencies in table 2, the initial hypothesis was rejected. Public and technical services practitioners did not respond differently and agreed on the importance of cataloging competencies for all entry-level academic librarians.

\section{Public and Technical Services: Core Competencies}

While there was overall agreement from both groups on the importance of all competencies, the means in tables 3 and 4 reveal slightly different priorities between public and technical services practitioners. Table 3 lists the eleven lowest means for public services respondents, and table 4 lists the ten lowest means for technical services respondents.

Though there is some agreement among the top competencies among public and technical services practitioners, the responses of the two groups did not entirely match. The view of the importance of six of the top ten competencies was commonly shared by both public and technical services respondents. The six similarly viewed competencies are:

- ability to read and interpret a bibliographic record in an OPAC

- understanding information-seeking behaviors of users

- knowledge of the ways in which searching techniques affect precision and recall

- knowledge of the theory of information organization and intellectual access

- Library of Congress Subject Headings

- understanding of the activities that must be performed to provide products and services users need

Public and technical services practitioners did not agree on the importance of the remaining four of the top

Table 2. Cataloging Competencies Viewed Differently, Public and Technical Services

\begin{tabular}{|c|c|c|c|c|c|c|c|}
\hline Competency & $\begin{array}{l}\text { All } \\
\text { No. }\end{array}$ & $\begin{array}{c}\text { All } \\
\text { Mean }\end{array}$ & $\begin{array}{l}\text { Public } \\
\text { No. }\end{array}$ & $\begin{array}{l}\text { Public } \\
\text { Mean }\end{array}$ & $\begin{array}{l}\text { Technical } \\
\text { No. }\end{array}$ & $\begin{array}{l}\text { Technical } \\
\text { Mean }\end{array}$ & Sig.* \\
\hline $\begin{array}{l}\text { Understanding of information-seeking } \\
\text { behaviors of users }\end{array}$ & 120 & 1.48 & 55 & 1.25 & 65 & 1.68 & .000 \\
\hline $\begin{array}{l}\text { Ability to evaluate information-retrieval } \\
\text { systems in relation to user needs and } \\
\text { information-seeking behaviors }\end{array}$ & 119 & 1.68 & 55 & 1.33 & 64 & 1.98 & .000 \\
\hline Library of Congress Classification & 119 & 1.76 & 54 & 1.59 & 65 & 1.91 & .014 \\
\hline $\begin{array}{l}\text { Knowledge of the basic database } \\
\text { design concepts }\end{array}$ & 119 & 2.00 & 54 & 1.81 & 65 & 2.15 & .015 \\
\hline HTML & 119 & 2.30 & 54 & 1.96 & 65 & 2.58 & .000 \\
\hline Cataloging tools: Basic knowledge of & 119 & 1.79 & 54 & 2.00 & 65 & 1.61 & .010 \\
\hline $\begin{array}{l}\text { Knowledge of principles for designing } \\
\text { user-driven information retrieval systems }\end{array}$ & 120 & 2.21 & 55 & 2.00 & 65 & 2.38 & .007 \\
\hline Anglo-American Cataloguing Rules & 119 & 2.08 & 54 & 2.31 & 65 & 1.89 & .006 \\
\hline $\begin{array}{l}\text { Knowledge of relevant national and } \\
\text { international cataloging standards }\end{array}$ & 119 & 2.15 & 54 & 2.42 & 65 & 1.92 & .000 \\
\hline
\end{tabular}


Table 3. Cataloging Competencies by Public Services

\begin{tabular}{|c|c|c|c|}
\hline Competency & No. & Mean & SD \\
\hline Ability to read and interpret a bibliographic record in an OPAC & 55 & 1.05 & .2993 \\
\hline Understanding of information-seeking behaviors of users & 55 & 1.25 & .4396 \\
\hline $\begin{array}{l}\text { Ability to evaluate information-retrieval systems in relation to user needs } \\
\text { and information-seeking behaviors }\end{array}$ & 55 & 1.33 & .5462 \\
\hline Knowledge of the ways in which searching techniques affect precision and recall & 55 & 1.44 & 6314 \\
\hline Library of Congress Classification & 54 & 1.59 & .6593 \\
\hline Knowledge of the theory of information organization and intellectual access & 55 & 1.64 & .6195 \\
\hline Library of Congress Subject Headings & 54 & 1.67 & .8009 \\
\hline Knowledge of the ways in which data structures affect precision and recall & 55 & 1.67 & .7467 \\
\hline $\begin{array}{l}\text { Understanding of the activities that must be performed to provide the products } \\
\text { and services users need }\end{array}$ & 54 & 1.68 & .7968 \\
\hline Understanding the relationship between classification schemes and shelf order & 54 & 1.68 & .7727 \\
\hline $\begin{array}{l}\text { Understanding the relationship of the research library's units to the provision } \\
\text { of intellectual access to information resources }\end{array}$ & 54 & 1.68 & .7479 \\
\hline
\end{tabular}

Table 4. Cataloging Competencies by Technical Services

\begin{tabular}{|c|c|c|c|}
\hline Competency & No. & Mean & SD \\
\hline Ability to read and interpret a bibliographic record in an OPAC & 65 & 1.15 & .4754 \\
\hline Knowledge of the theory of information organization and intellectual access & 65 & 1.54 & .7721 \\
\hline Knowledge of the ways in which searching techniques affect precision and recall & 65 & 1.61 & .6045 \\
\hline Cataloging tools: Basic knowledge of & 65 & 1.61 & .7222 \\
\hline Understanding of information-seeking behaviors of users & 65 & 1.68 & .7095 \\
\hline MARC format & 64 & 1.70 & .8102 \\
\hline Awareness of bibliographic utilities & 65 & 1.72 & .7605 \\
\hline \multicolumn{4}{|l|}{ Understanding of the activities that must be performed to provide the products } \\
\hline and services users need & 65 & 1.74 & .6679 \\
\hline Library of Congress Subject Headings & 65 & 1.80 & .7115 \\
\hline Classification: Knowledge of theory & 64 & 1.81 & .7741 \\
\hline
\end{tabular}

ten competencies. The remaining top competencies of public services competencies practitioners are:

- ability to evaluate information-retrieval systems in relation to user needs and information-seeking behaviors

- Library of Congress Classification

- understanding the relationship between classification schemes and shelf order

- understanding the relationship of the research library's units to the provision of intellectual access to information resources

Technical services practitioners completed their top ten competencies with the following:

- basic knowledge of cataloging tools

- MARC format

- awareness of bibliographic utilities

- knowledge of theory of classification

One possible explanation for the disagreement on the remaining competencies could be the perspective of the respondents. It can be argued that of the top ten competencies, the four remaining ones from each group are more in line with the respondents' specific job duties. The remaining public services competencies appear to be more user-oriented and broad whereas the remaining technical services competencies are more task-oriented. To summarize, there is a good deal of agreement between public and technical services practitioners concerning cataloging competencies, though the exact ranking of core competencies varies from group to group.

The final research question concerned practitioners' views of the importance of practical cataloging knowledge compared to theoretical cataloging knowledge and whether one is more important than the other. The researchers hypothesized that respondents would rank theoretical knowledge as more important than practical knowledge, but results led to the rejection of this hypothesis. Respondents actually view theoretical and practical competencies in a similar light with theory ranking only slightly higher than practice. Respondents' views of the importance of theoretical and practical knowledge are shown in table 5. For all competencies in table 5 , a greater percentage of respondents do indeed rank theoretical knowledge as more essential than practical 
knowledge. However, for each of the paired theoretical-practical competencies, the number of respondents who rank practical knowledge as important is similar to the number who rank theoretical knowledge as important. In each of the paired theoretical-practical competencies, the theoretical competency has the higher percentage of respondents ranking the competency as essential, but in the important category, values for each are similar. The results suggest that both theoretical and practical competencies are of value with theoretical competencies ranking slightly higher.

Next, respondents' views of knowledge of traditional cataloging tools were analyzed in order to see whether practitioners believe this knowledge is still relevant. Rankings (by all respondents) for the traditional cataloging tools (Library of Congress Subject Headings, Library of Congress Classification, MARC format, Anglo-American Cataloguing Rules, Library of Congress Rule Interpretations, and Dewey Decimal Classification) are listed in table 6 by percentage. The $\mathrm{N}$ value represents the actual number of responses received for each question. In the case of all of the traditional cataloging tools, a small number of participants either skipped questions or chose not to answer.

Knowledge of Library of Congress Subject Headings, Library of Congress Classification, MARC format, and Anglo-American Cataloguing Rules are viewed by the majority of respondents as solidly in the important or essential categories. In fact, both Library of Congress Subject Headings and Library of Congress Classification are ranked as core competencies with means of 1.74 and 1.76, respectively (see table 1). Library of Congress Subject Headings are viewed as either essential or important by $83.2 \%$ of the respondents while Library of Congress Classification is viewed as either essential or important by $84.9 \%$ of the respondents. The MARC format is viewed as either essential or important by $79.4 \%$ of the respondents.
The top three tools from table 6 (Library of Congress Subject Headings, Library of Congress Classification, and MARC format) are all related to basic user tasks and browsing. They are also the only traditional cataloging competencies to appear in either the public or technical services top ten list (see tables 3 and 4). Thus, traditional cataloging tools such as Library of Congress Subject Headings, Library of Congress Classification, and the MARC format are viewed as being either essential or important by more than $75 \%$ of the respondents, suggesting that academic library practitioners in both public and technical services view knowledge of traditional cataloging tools of continuing relevance for entry-level academic librarians.

In addition to the traditional cataloging tools, competencies dealing with cataloging innovations and emerging standards were included on the survey to measure the perceptions of practitioners of the importance of knowledge of these innovations for all entry-level academic librarians. The three developing standards examined include HTML, Dublin Core, and the Program for Cooperative Cataloging Core Record Standard. Table 7 lists by percentage the three developing standards as ranked by all participants. These results clearly demonstrate that knowledge of HTML, Dublin Core, and the Core Record Standard are perceived by the majority of respondents as desirable but not necessary. However, it is important to note that among the group of public services practitioners, knowledge of HTML is ranked much higher. With a mean of 1.96 (see table 2), HTML is considered a core competency by the public services practitioners.

\section{Discussion}

This survey demonstrates the existence of a definite set of core cataloging competencies for entry-level academic

Table 5. Importance of Theoretical and Practical Knowledge

\begin{tabular}{|c|c|c|c|c|}
\hline \multicolumn{5}{|c|}{ Percent of All Respondents Ranking Tool As: } \\
\hline Competency & Essential (1) & Important (2) & $\begin{array}{r}\text { Desirable but not } \\
\text { necessary (3) }\end{array}$ & Unimportant (4) \\
\hline Subject analysis: Knowledge of theory $(N=119)$ & 29.4 & 49.6 & 19.3 & 1.7 \\
\hline Subject analysis: Knowledge of methods for $(N=117)$ & 19.7 & 50.4 & 27.3 & 2.6 \\
\hline Thesaurus creation: Knowledge of theory $(N=120)$ & 18.3 & 43.3 & 37.5 & 0.8 \\
\hline Thesaurus creation: Knowledge of methods for $(N=118)$ & 6.8 & 37.6 & 52.5 & 3.3 \\
\hline Indexing: Knowledge of theory $(N=119)$ & 22.7 & 44.5 & 31.9 & 0.8 \\
\hline Indexing: Knowledge of methods for $(N=118)$ & 11.9 & 43.2 & 42.4 & 2.5 \\
\hline Classification: Knowledge of theory $(N=118)$ & 33 & 48.3 & 17.8 & 0.8 \\
\hline Classification: Knowledge of methods for $(N=117)$ & 18.8 & 47.9 & 32.5 & 0.8 \\
\hline $\begin{array}{l}\text { Describing, identifying, and showing relationships among } \\
\text { materials: Knowledge of theory }(N=120)\end{array}$ & 29.2 & 52.5 & 18.3 & 0.0 \\
\hline $\begin{array}{l}\text { Describing, identifying, and showing relationships among } \\
\text { materials: Knowledge of methods for }(N=119)\end{array}$ & 19.3 & 53.8 & 26 & 0.8 \\
\hline Cataloging tools: Basic knowledge of $(N=119)$ & 44.5 & 33.6 & 20.2 & 1.7 \\
\hline Cataloging tools: Working knowledge of $(N=116)$ & 16.4 & 37.9 & 41.4 & 4.3 \\
\hline
\end{tabular}


Table 6. Importance of Knowledge of Traditional Cataloging Tools

\begin{tabular}{|c|c|c|c|c|}
\hline \multicolumn{5}{|c|}{ Percent of All Respondents Ranking Tool As: } \\
\hline Competency & Essential (1) & Important (2) & $\begin{array}{l}\text { Desirable but not } \\
\text { necessary (3) }\end{array}$ & Unimportant (4) \\
\hline Library of Congress Subject Headings $(N=119)$ & 43.7 & 39.5 & 16.0 & 0.8 \\
\hline Library of Congress Classification $(N=119)$ & 38.7 & 46.2 & 15.0 & 0.0 \\
\hline MARC format $(N=117)$ & 44.4 & 35.0 & 17.1 & 3.4 \\
\hline Anglo-American Cataloguing Rules $(N=119)$ & 28.6 & 37.0 & 31.9 & 2.5 \\
\hline Library of Congress Rule Interpretations $(N=119)$ & 17.6 & 25.2 & 43.7 & 13.4 \\
\hline Dewey Decimal Classification $(N=118)$ & 6.8 & 28.0 & 44.1 & 21.2 \\
\hline \multicolumn{5}{|l|}{ Table 7. Knowledge of Cataloging Innovations } \\
\hline \multicolumn{5}{|c|}{ Percent of All Respondents Ranking Tool As: } \\
\hline Competency & & & $\begin{array}{l}\text { Desirable but not } \\
\text { necessary (3) }\end{array}$ & Unimportant (4) \\
\hline $\operatorname{HTML}(N=119)$ & 20.2 & 32.8 & 43.7 & 3.4 \\
\hline Dublin Core $(N=114)$ & 10.5 & 27.2 & 52.6 & 9.6 \\
\hline Core Record Standard $(N=114)$ & 9.6 & 28.9 & 50.0 & 11.4 \\
\hline
\end{tabular}

librarians as perceived by public and technical services practitioners in academic libraries. There is also a strong agreement between public and technical services practitioners on the competencies themselves. These results appear to refute the argument made by Fallis and Frické (1999) that cataloging education is inappropriate for graduate level education. The researchers conclude that academic libraries, in particular, need librarians with a basic understanding of cataloging in order to provide the best possible service for students, faculty, and the larger community.

Intner (1989) describes the prevailing myth about cataloging education that only students who desire cataloging careers apply for cataloging jobs. In reality, entry-level academic librarians possess varying degrees of knowledge and may not necessarily accept a position in an area corresponding to their coursework. As results of this research suggest, cataloging education is needed for all academic librarians, not just catalogers. Hence, to overlook cataloging education in graduate education is shortsighted and does not reflect the views of the practicing academic librarians surveyed, who clearly believe that a definite set of core cataloging competencies exists for all entry-level academic librarians.

The cataloging competency most highly valued by both public and technical services practitioners is the ability to read and interpret a bibliographic record in an OPAC. The survey examined both broad and narrow cataloging competencies. While practitioners view the broad competency of the ability to read and interpret a bibliographic record in an OPAC as essential, it does not mean that the narrower competencies encompassed by the ability to read and interpret a bibliographic record in an OPAC are of lesser value. One librarian commented, "I'm teaching an introductory refer- ence course this fall and it's very difficult when the students haven't had a basic cataloging course (which is not required), as they don't understand concepts such as MARC record, field, subject heading, descriptor, corporate author, etc. Knowledge of cataloging is essential to knowing how to retrieve information." Consequently, the narrower, more specifically cataloging-focused competencies and OPACrelated competencies are also needed in order to successfully read and interpret a bibliographic record in an OPAC.

Beyond the ability to read and interpret a bibliographic record in an OPAC exists the realm of electronic resources. With their unique characteristics, they are altering the traditional landscape for both public and technical services. Emerging models for the provision of access to this complex and dynamic group of resources suggest that though the creation of resource descriptions has, until recently, been highly centralized within technical services units, this will no longer be the case in the future. The creation of resource descriptions, so long the province of the catalogers, will be shared among various players in the library community, including selectors, reference staff, acquisitions staff, cataloging staff and information technology staff (Calhoun 2000). Thus, it will become increasingly important that librarians in all areas of the field possess basic cataloging competencies as it is likely that the creation of resource descriptions will become everyone's responsibility.

The need for authority control, for standardized description, and for effective strategies to deal with both dynamic resources and resources that embody the same intellectual content in multiple formats, will become increasingly important (Huthwaite 2000). Thus, there will be a continued need for librarians to understand such basic 
cataloging concepts as the controlled vocabulary, creation of controlled headings for names and titles and methods for standardized resource description. The end product may look quite different from a traditional MARC cataloging record, but there will continue to be a great need for librarians who understand these underlying concepts.

Finally, the results demonstrate that practitioners view both theory and practice as important within the list of cataloging competencies. In general terms, theory was valued only slightly higher than methodology or a working knowledge. Thus, practitioners do not appear to view theory as operating in a vacuum apart from practice or vice-a-versa; they recognize the need for practical as well as theoretical knowledge.

The survey contains some limitations as a result of the relatively narrowly defined sample. Only large academic libraries with membership in the ARL were surveyed. The study focused on academic librarians, omitting large research libraries without formal academic affiliation (e.g., Library of Congress). Also, among the ARL academic members, only heads of reference and heads of cataloging were contacted. The results might have been quite different had those in other specialties been contacted (systems librarians, bibliographers, etc.). And finally, academic librarians at smaller two-year and other four-year institutions were omitted from the sample.

Areas for future study of core cataloging competencies for all entry-level academic librarians appear promising. One avenue is to expand the pool to include academic librarians beyond the ARL institutions initially surveyed (two-year institutions, colleges, non-ARL institutions, etc.). Another possible direction is to survey groups beyond heads of reference and heads of cataloging to see how other specialties within academic libraries view core cataloging competencies for all entry-level academic librarians. Of these, perhaps the most interesting direction for future study is to administer the survey to library educators to see if they believe it is important for students going into academic librarianship to possess a definite set of core cataloging competencies.

\section{Conclusion}

The survey and the discussion of the findings demonstrate the importance of cataloging education for all entry-level academic librarians and the existence of a basic set of core cataloging competencies as viewed by public and technical services practitioners in academic libraries. As noted in the literature review, Spillane (1999) documented a general decrease in the required number of cataloging courses offered in ALA-accredited programs. However, a distinct gap exists between the state of cataloging education in ALAaccredited programs as reported by Spillane and the views of the public and technical services practitioners in academic librarians surveyed in the study. The public and technical services practitioners in academic libraries view cataloging education and core cataloging competencies as valuable for all entry-level academic librarians. The quality of preparation of entry-level practitioners is a vital issue for the profession, with much at stake for both educators and libraries. The quality of preparation bears a direct relation to the costs of training and the effectiveness of the newest members of the profession. How should educators approach the apparent gap between the existing cataloging curriculum and the needs of public and technical services practitioners in academic libraries as expressed in this survey? How should educators prepare entry-level academic librarians? This study suggests that basic cataloging education continues to be valuable for all entry-level academic librarians. Perhaps the time is ripe for renewed dialogue between practitioners in academic libraries and library educators on the role of cataloging education in the graduate curriculum, and the content of cataloging courses. Clearly, a closer partnership between library educators and library practitioners is essential as the profession wrestles with the questions of how best to prepare librarians to serve in an increasingly complex information environment.

\section{Works Cited}

American Library Association. 1999. Congress on Professional Education: Focus on education for the first professional degree. Accessed March 26, 2001, www.ala.org/congress/1st_ congress.html.

Association for Library Collections and Technical Services. 1995. ALCTS Educational Policy Statement. Accessed March 27, 2001, www.ala.org/alcts/publications/educ/edpolicy.html.

Buttlar, Lois, and Rosemary Ruhig DuMont. 1989. Assessing library science competencies: Soliciting practitioner input for curriculum design. Journal of Education for Library and Information Science 30(1): 3-18.

Calhoun, Karen. 2000. Redesign of library workflows: Experimental models for electronic resource description. Accessed April 16, 2001, http://lcweb.loc.gov/catdir/bibcontrol/calhoun_paper.html.

CCS Task Force on Education and Recruitment for Cataloging report, June 1986. 1986. RTSD Newsletter 11(7): 71-78.

Fallis, Don, and Martin Frické. 1999. Not by library school alone. Library Journal 124(17): 44-45.

Gorman, Michael. 1999. Metadata or cataloguing? A false choice. Journal of Internet Cataloging 2(1): 5-22.

Green, Tim C. 1993. Competencies for entry-level independent information professionals: An assessment by practitioners. Journal of Education for Library and Information Science 34(2): 165-68.

Hill, Debra W. 1997. Requisite skills of the entry-level cataloger: A supervisor's perspective. Cataloging and Classification Quarterly 23(3/4): 75-83. 
Hopkins, Judith. 2000. Directory of North American research libraries: A staff directory. Accessed March 28, 2001, http://ublib.buffalo.edu/libraries/units/cts/directory.

Huthwaite, Ann. 2000. AACR2 and its place in the digital world: Near-term revisions and long-term direction. Accessed May 8, 2001, http://cweb.loc.gov/catdir/bibcontrol/huthwaite.html.

Intner, Sheila S. 1989. Responding to change: New goals and strategies for core cataloging courses. In Recruiting, educating and training cataloging librarians: Solving the problems, ed. by Sheila S. Intner and Janet Swan Hill, 227-43. New Directions in Information Management, no. 19. New York: Greenwood.

MacLeod, Judy, and Daren Callahan. 1995. Educators and practitioners reply: An assessment of cataloging education. Library Resources and Technical Services 39(2): 153-65.

McAllister-Harper, Desretta. 1993. An analysis of courses in cataloging and classification and related areas offered in sixteen graduate library schools and their relationship to present and future trends in cataloging and classification and to cognitive needs of professional academic catalogers. Cataloging and Classification Quarterly 16(3): 99-123.

Morris, Dilys E., and Gregory Wool. 1999. Cataloging: Librarianship's best bargain. Library Journal 124(11): 44-46.
Powell, Ronald R., and Sheila D. Creth. 1986. Knowledge bases and library education. College and Research Libraries 47(1): 16-27.

Riemer, John J. 1993. A practitioner's view of the education of catalogers. Cataloging and Classification Quarterly 16(3): 39-48.

Ryans, Cynthia C. 1980. Cataloging administrators' views on cataloging education. Library Resources and Technical Services 24(4): 343-51.

Speller, Benjamin F. Jr. 1993. Putting theory into practice: An overview of the symposium. Cataloging and Classification Quarterly 16(3): 1-6.

Spillane, Jodi Lynn. 1999. Comparison of required introductory cataloging courses, 1986 to 1998. Library Resources and Technical Services 43(4): 223-30.

Urbanski, Verna. 1992. Fear and loathing in library science. Journal of Education for Library and Information Science 33(1): 58-63.

Vellucci, Sherry L. 1997. Cataloging across the curriculum: A syndetic structure for teaching cataloging. Cataloging and Classification Quarterly 24(1/2): 35-59.

White, Herbert S., and Marion Paris. 1985. Employer preferences and the library education curriculum. Library Quarterly 55(1): 1-33. 